From Needs to the Market: Changing Inequality of Household Income in the Czech Transition

\author{
By: Jiri Vecernik
}

Working Paper No. 370

April 2001 


\title{
From Needs to the Market: Changing Inequality of Household Income in the Czech Transition
}

\author{
Jiri Vecernik \\ Institute of Sociology, Academy of Sciences \\ Jilska 1, 11000 Praha 1, Czech Republic \\ e-mail:vecernik@soc.cas.cz
}

\begin{abstract}
Statistical income surveys are used to document systemic changes in distribution and redistribution of household income and its determinants over the period 1988-1996. First, the growing difficulties facing income surveys under the democratic regime are considered. Secondly, the substantive meaning of various income indicators and their relation to the social and economic situation is discussed. Next, growing disparities in income after 1989 and the shift away from demographic factors (numbers of active earners and children, age) to socioeconomic factors (education, branch, occupation) are displayed. The fourth part documents the increased redistribution of income achieved through taxes and social benefits. The fifth part compares the Czech case with Western countries in order to evaluate the extent to which income distribution has adjusted to the market economy. The conclusion offers a summary of main findings and discusses some additional resources of family welfare during the transition period.
\end{abstract}

Key words: household income, income inequality, Czech Republic, redistribution, market adjustment.

JEL Classification: $\mathrm{I} 30, \mathrm{~J} 30$ 


\section{Non-technical Summary}

Using three large statistical surveys of household income, we observe changes in the range and structure of income, and examine whether the Czech Republic is approaching a market model. Our ambition is to survey not only changes in disparities, but also to study qualitative changes in the income distribution system. We reflect on the methodological difficulties of income surveys. Then we investigate to what degree income indicators reflect the character of the political regime and economic system. Further, we analyze the main changes in income distribution and their causes. Then we concentrate on the redistribution of income through taxes and social benefits, and lastly we show the extent to which Czech income has adjusted to the market by employing comparative data from Western countries.

Between 1988 and 1996, the range of income inequality increased considerably. The income hierarchy remained fixed at the bottom, and opened up, reducing income share of middle categories. Whereas in 1988, pensioners almost exclusively occupied the bottom decile, to a considerable extent they moved to the lower middle income ladders to be partly replaced by families with children. Household income is much less determined by demographic variables today than in the former regime. From the other side, the importance of labor market characteristics of adult family members increased. In the structure of income per capita, education tripled in importance. Data indicate that the income position of non-manual and educated workers improved while the number of manual and less skilled people worsened.

With regard to income redistribution, the state takes more from and gives less to households. Number of children is no longer the prominent factor of both taxes and transfers as it was in the communist regime. Instead, household income has become the dominant determinant of taxes, and also a more important determinant of social transfer. At the same time, flows of redistribution strengthened, be it in connection with tax reform (more progression) or social reform (more targeting). The equalizing intervention of the state in favor of the poor and near-poor (and to the detriment of the middle classes) appears to be very high in comparison with even the most redistributive Western countries.

The changing income structure represents part of the general trend that is reintroducing the Czech Republic to the family of 'standard' market countries. In income per household, disparities are still higher in the Czech Republic than in West European countries. In contrast, the disparity of per capita income reached the level of 'socially generous' Western countries (Belgium and Sweden). In determination of household income, the weight of demographic factors weakens and dependency of household income on labor market participation and the human capital of adult members strengthens. Regarding the level and degree of redistribution through taxes and social transfers, the Czech Republic much more redistributive in taxes and considerably more redistributive in social benefits that any other OECD country under observation.

The available variables do not allow us to compare the labor market and human capital characteristics of households across countries and thus to document more precisely the current situation in the Czech Republic. Nevertheless, even with the indicators at our disposal, it can be concluded that the distribution of household income in the Czech Republic is much less different from Western countries regarding inequality and its structure in 1996 than in 1988. Only the equalizing effect of taxes and social benefits continues to be rather extreme: a huge amount of transfers (as in social-democratic countries) is combined with a steep slope of redistribution (as in liberal countries). 


\section{Introduction}

In the second half of the twentieth century, the Czech nation, located in the troubled heart of Europe, experienced two radical changes of regimes. The first was in 1948, when the communists seized power and went on to implement their doctrine in its most repressive form until the mid-1950s. Forty years later, economic reform, involving large-scale privatization and liberalization, heralded a 'return to the market'. The first change of regime - the 'communist revolution' - outwardly proclaimed an ideology of equality. However, it followed the Soviet model of how to feed more workers on less. As a consequence, wages were equalized, and need and loyalty became the main criterion of reward. The second regime change - the 'capitalist counter-revolution' - aimed at de-equalizing earnings, re-introducing market competition and re-creating income from business.

The empirical observations of these two political upheavals in income distribution stand in stark contrast to each other. There are no reliable income surveys from the period before or immediately after 1948 . Thus, the picture can only be composed from a mosaic of various data, such as pension fund registers of wages, branch statistics of wages, and nonrepresentative Family Expenditure Surveys. By the time the first solid wage and household income surveys were launched in 1956, an entirely new system of distribution was already in place. In contrast to missing data from the first regime change, there are adequate and reliable data sources for the second change. Three household surveys conducted by the Czech Statistical Office (CSO) are already available covering the period 1988-1996.

Immediately after 1989, the Czech Republic metamorphosed from one of the most hardline communist countries into a democratic country with a largely privatized economy. Its GDP in constant prices decreased considerably in 1991, not reaching its 1989 level again until 1996. The average wage increased at a higher rate than productivity of labor, but social benefits rose by a significantly smaller amount. Until 1996, the Czech Republic was at the forefront of the transition countries in terms of basic macroeconomic indicators and the speed of (formal) privatization. Wage and household income inequality rose. Education, formerly suppressed, became an important factor in individual careers and earnings. In 1996, social transfers and taxes became more transparent and redistribution more progressive. In a sense, this year marks the accomplishment of important changes which were not, however, successfully continued through the rest of the decade.

In this paper we focus on the second of the two changes of political regime. The available statistical data give us a unique opportunity to investigate changes introduced by the restored market system. Our ambition to survey not only changes in disparities, but also to study qualitative changes in the income distribution system. In the next part, we reflect on the methodological difficulties of income surveys. The third part investigates to what degree income indicators reflect the character of the political regime and economic system. In the fourth part, we analyze the main changes in income distribution and their causes. The fifth part concentrates on the redistribution of income through taxes and social benefits, while the sixth part shows the extent to which Czech income has adjusted to the market by employing comparative data from Western countries. In conclusion, the main findings are summarized and some additional resources of family welfare are discussed. 


\section{Increased difficulty in ascertaining income}

The methodology used to conduct income surveys changed with the political regime. Under the totalitarian regime, the refusal rate for participation in surveys was low, because even if a survey was not expressly designated as compulsory, people were afraid to refuse to comply with any official inquiry. The most important sources of income were directly transferred by the state administration - the wages of individual workers were passed on by their employer organizations and pension benefits were reported by the post offices that distributed them. The communist government commissioned large surveys as a means of demonstrating the regime's achievements in 'increasing the standard of living of working people'. Consequently, income surveys were highly - at least with regard to the formal economy.

After four decades of basically one income source, 'capitalist' profits became legitimate income alongside 'working class' wages and social benefits. Since 1990, the share of earnings from state-dependent activities has decreased, while the share of income from selfemployment and entrepreneurship has been slowly rising. Instead of uniformity, we are now presented with a wider variety of economic status and also their mixture like combination of dependent full-time employment with independent part-time employment.

\section{Table 1}

The growing obstacles to income inspection can be documented in the three income surveys cited here (Table 1). From various reasons, the previous method of directly transferring income information from state organizations had to be abolished after 1989. The coverage of surveyed income in comparison with calculations of National Accounts has decreased substantially, this despite corrections made by statisticians after the collection of data. Such problems are, however, quite common to income surveys. ${ }^{\text {E }}$ Yet despite these shortcomings, income surveys carried out by the CSO constitute the best, if not the only, representative source of information on household incomes in this country (the Family Expenditures Survey is not appropriate for this study because it is not based on a random sample in the Czech Republic).

\section{Income indicators as social constructions}

To reflect upon the matter, income distribution is a 'social construct', rather than a given fact, as is the case with poverty (Rainwater, 1994). The results depend largely on the income concept chosen, the selection of which is not entirely free of value judgement and political considerations. Basically, we can chose to take as our indicator from among income per household, income per capita, or something 'in between', which means household income calculated per equivalent unit. The large diversity of equivalence scales was exhibited in the LIS comparative analysis (Buhman et al., 1988; Atkinson, Rainwater and Smeeding, 1995).

\footnotetext{
${ }^{1}$ According to the Labor Force Survey, 4 per cent of entrepreneurs and 7.7 per cent of self-employed persons were at the end of 1996. Combining LFS with the number of licenses issued, we estimate the number of people in full-time employment with a business license as constituting up to 15 per cent of the labor force. Most of their extra income is not registered in income surveys. In Microcensus 1996, only 0.3 per cent of economically active persons declared amounts of income from secondary self-employment.

${ }^{2}$ The figures on coverage released by the Czech Statistical Office differ from our calculation and cite 87, 86 and 93 per cent in consecutive years. According to the LIS study (Atkinson, Rainwater and Smeeding, 1995:34), the ratio of survey estimates to National Accounts estimates ranged from 77 per cent (Germany in 1981) to 92 per cent (Canada in 1981).
} 
According to this analysis, the continuum of possibilities is expressed by the elasticity coefficient in the formula:

$$
W=D / S^{e}
$$

where $W=$ economic well-being, $D=$ total disposable income, $S=$ size of household and exponent $e=$ elasticity coefficient. The elasticity coefficient varies between 0 (full-scale economies) and 1 (no scale economies). In 'communist' statistics, income per capita was the only indicators used. This means that each person was given the same weighting, without regard to age, and no economies of scale were assumed. By contrast, in 'Western' statistics total disposable household income served as the most frequent indicator for a long time. This difference was already apparent in the first East/West comparison of income (Incomes, 1967) as well as in another comparison by Wiles (1978), and was most recently commented by Flemming and Micklewright (1999).

In the past, it was quite common to begin any East-West comparison of incomes with the statement that communist societies displayed an extreme equalization of income (e.g. Wiles, 1974; Atkinson and Micklewright, 1992). Such a position is certainly well founded if we use income adjusted per capita. However, once we begin to look at the indicator of income per household or any equivalent unit acknowledging larger scale economies, the range of inequality appears to be higher. More specifically, while the pre-1989 figures on inequality of per capita income in Czechoslovakia are among the lowest in the world, figures on inequality of income per household are close to, if not higher, than those in Western countries (Vecernik, 1986).

Why did distribution in the former Czechoslovakia (and probably also in other communist countries) differ so greatly from Western countries in income per capita and so little in terms of income per household? In Western countries, employment of women was low and disparities in earnings of the main breadwinner were thus the main source of inequality in household incomes. In Eastern European countries, and especially in the former Czechoslovakia (where wages were extremely equalized and employment of women was the highest), inequality in household income was predominantly determined by the number of family members active in the labor market and the economic status of the head of household. Concretely speaking, one-pensioner households occupied the bottom of the income distribution, while rural families with several active earners dominated the top.

The most obvious reason for using the indicator of income per household in Western literature is because it can be taken from the best available source for examining income inequality - tax statistics. Since the 1980s, income distribution has usually been analyzed using incomesurveys and authors refer to income adjusted to household size and composition. In communist countries, income surveys were the sole source. We can also speculate as to whether presenting only income per capita statistics was an effort to hide actual income disparities in the country. In any case, this income indicator is well suited to the 'need principle', according to which economic life was organized under communism, as opposed to the 'market principle' implicitly or explicitly prevailing in capitalist regimes (Vecernik 1996 and 1999).

The 'need principle' refers to a primary focus on the basic needs of the reproduction of individuals, who are largely viewed as 'soldiers of labor'. This principle was explicitly

\footnotetext{
${ }^{3}$ However, as the LIS study documents, countries such as France, Italy, the Netherlands and the United Kingdom still use non-adjusted household income (Atkinson, Rainwater and Smeeding 1995:54).
} 
formulated by Marx ([1867]1965) as a prominent mechanism for the reward (and exploitation) of hired labor by capitalists. The owners of the means of production do not pay for the worker's labor itself, but for the reproduction of his labor force. While capitalism itself refused to follow this logic (resulting in the forecasted impoverishment of the working class), communist regimes achieved it through reducing disparities and deriving wages from the different manual force invested. In contrast, the 'market principle' can be viewed as an assertion of the relationship between a person's job, including invested skills and the quality of work done.

The use of income per capita under the communist regime was indeed endorsed by a particular structure of consumption. Here, the cost of individually 'divisible items' such as food and clothing was higher, while the common costs of households such as housing and

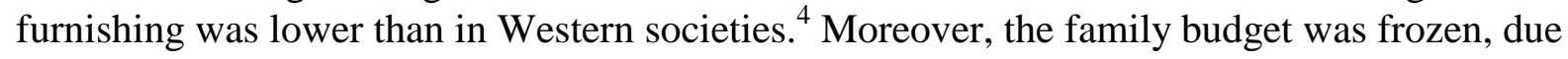
to state manipulation of consumer prices: the consumption of food was encouraged through price subsidies and the consumption of durable goods was prohibited through shortages and high taxes on prices. Housing in state apartments was cheap (and correspondingly bad) and thus did not place much of a burden on the family budget, accounting for about 6-7 per cent of net expenditures.

In our view, the various use and the different explanatory power of individual income indicators is not an artifact. Income measures should correspond to the way household income is actually collected and utilized, which differs across regimes and countries. After efforts to eliminate the family as an institution failed, communist societies aimed at least to reduce its power through employment, wage and price policies that always stressed individuals and their needs. However, in the same way that infinite scale economies are not possible (as the indicator of total household income implies), neither were zero scale economies possible (as the indicator of per capita household income suggests).

This also means that while disparities of total household income certainly overestimated the inequality of welfare in the West (unless the total household income was used), disparities of per capita income underestimated inequality in the East (where the indicator of per capita income was widespread). As Buhman et al. (1988) suggest, the reality is always somewhere 'in between' and individual countries in various periods of their life can be located on the large continuum of coefficient $e$, according to the price and consumption structure. Instead of the difficult inspection of the 'best' equivalence scale, most research utilizes one calculation based largely on a rule of thumb, be it the EU, OECD or LIS equivalence scale.

\section{Schema 1}

We acknowledge its usefulness for comparison across countries and time and do not intend to criticize all simplifications of such an equalizing method because any country and time specific approach is fraught with difficulties. Our aim here is to show extensive changes introduced by the transition in the determination of earnings, the packaging of family income and the price structure. We argue that there are not only quantitative changes in range of disparity and its correlates, but that behind such shifts, the qualitative character of the whole system of income distribution is modified: the system corresponding to command economy is

\footnotetext{
${ }^{4}$ Flemming and Micklewright (1999:25) also consider income per capita to be 'more appropriate for socialist societies on account of the lower fixed costs of households due to subsidized prices of housing and fuel'.

${ }^{5}$ In the OECD scale, first adult $=1.0$, other adults $=0.7$ and each child $=0.5$. In the LIS scale, first adult $=1.00$, other adults $=0.66$ and each child $=0.33$. In the square root approach, square root of the number of household members so that 2-person household equals 1.41 of equivalent adult, 3-person household 1.73, etc.
} 
replaced by another, typical of the market economy. Schema 1 stylizes the different patterns of income distributions typical for different regimes.

In this study, we observe disposable household income which equals the gross market income plus state transfers, after accounting for personal taxes and social insurance contributions. We use two 'extreme' indicators of income: the first is total disposable household income (per household) and the second household income adjusted per household members (per capita). In the second case, households are weighted by the number of household members, in line with the LIS method (Atkinson, Rainwater and Smeeding, 1995). The reason for employing both measurements is to inspect their individual shifts and the changing relation between both income indicator measurements. We suspect that, combined with the other evidence, they testify important changes in the Czech income structure.

\section{Market adjustment in range and structure}

Leaving aside any exaggerated optimism, in the period 1990-1996 the Czech Republic undertook several important steps towards a market economy (Vecernik, 1996). In the income sphere in particular, economic reform allowed for an increase in the formerly frozen differences in earnings through new private business, foreign firms and less strict (and soon released) wage regulation. In social security, the privileges of the ruling class were abolished and valorization rules (previously non-existent) were introduced. It also allowed for other sources such as income from property and financial speculation, and led to the expansion of income from the informal economy.

\section{Table 2}

Inequality of disposable household income has been rising in the period 1988-1996 (Table 2 ). This rise is slower for per household income and faster for per capita income. Whereas the correlation between income per household and the number of active earners as well as between per capita income and dependent children is weakening, the correlation between the two income indicators is strengthening. This indicates that disparities in family earnings are growing sufficiently wide to prevail over the number of active family members. ${ }^{6}$ The high correlation of various adjustments in household income shows that there is little sense in employing other equivalence scales in parallel to examine income inequality.

Disparity between shifts in distribution of income per household and per capita is explained by the changing composition of households. While the average size of households in the period 1988-1996 remained unchanged (2.66 members) and the number of dependent children fell slightly (from 0.76 to 0.69 ), the number of economically active members decreased considerably (from 1.48 to 1.24). Two different causes have contributed to this: the pressure on working pensioners to leave the labor force (compelled by heavy taxation of their earnings)and the pressure on women to stay at home or support their husbands in their business.

\footnotetext{
${ }^{6}$ According to Microcensus surveys, the Gini coefficient of wages of all economically active workers rose from 0.19 in 1988 to 0.24 in 1996.

${ }^{7}$ The first scale is the steepest (in Buhman's et al. formula $\mathrm{e}=0.74$ ), the second moderate $(\mathrm{e}=0.64)$ and the third the flattest $(\mathrm{e}=0.50)$.

${ }^{8}$ Between 1988 and 1996, the share of households in prime age (25-54 of the head) with a single active earner increased from 29.7 to 36.7 per cent, while the average of economically active members in those households decreased from 1.86 to 1.82 .
} 


\section{Table 3}

Table 3 shows income distribution by deciles. According to income per household, the share of bottom decile increased slightly while the share of top decile rose considerably. According to income per capita, the top decile also increased its share, but the rest changed unevenly in the two periods. Between 1988 and 1992, the relative position of the lower half was largely maintained while the upper half (but not the very top) declined somewhat. This was the 'pre-privatization period' of the social-liberal government which maintained universal social benefits and kept wages under control. Between 1992 and 1996, relative stability or even an increase was registered in the upper half while the lower half lost out. This was the 'privatization period' of the self-declared liberal government, which replaced universal with targeted benefits, removed wage regulation, froze the minimum wage, and allowed for a rapid rise in earnings not supported by a growth in the productivity of labor.

In both periods, the middle of the income distribution was squeezed. In terms of real disposable income per household, the lowest and highest income categories increased their living standards, while middle incomes lost 10-20 per cent of their purchasing power. However, the rising share of the bottom decile is somewhat spurious because there was considerable demographic mobility within it, as shown below. In terms of income per capita, only the top decile gained, while the bottom decile lost the most. The results given by the two income indicators are disproportionate, thereby indicating the uneven change in various categories of the population and the modification of the income hierarchy in sociodemographic terms. In spite of this, the middle class has not enjoyed significant gains from the transition (Vecernik, 1999).

\section{Table 4}

Table 4 shows the distribution of pensioners and children size in individual deciles. The most apparent change was that pensioners were replaced by children in the lower part of the income distribution. While in 1988, the share of first decile of total disposable income was composed exclusively of pensioners, who also accounted for two-thirds of the second decile, by 1996 to both of these deciles had been entered children. In other words, the lowest income had ceased to be represented exclusively by transfer incomes (pensioners $=$ non-working poor $=$ 'old' poverty) and had become newly represented by low market incomes (families with children $=$ working poor $=$ 'new' poverty).

Instead of other cross-sections (by education, type of occupation and size of locality), we use a multivariate analysis. The main purpose is to compare two sets of income predictors: 1 . demographic or life-cycle variables (age, the size and composition of households) and 2. economic or labor market variables (education and occupation). The methodological difficulty arises from the fact that, although the 'demography' of a family is relatively easily indicated and represented in all income surveys, the specification of 'labor market capacities' is not easily obtained and is not comparable across all surveys.

\section{Table 5}

In the analysis of variance (Table 5), only households with the head in prime age (25-54) are included. This allows us to display the changing proportions of 'demographic' and 'economic' factors in households participating in the labor market. We observe a weakening

\footnotetext{
${ }^{9}$ In the 1988 Microcensus, only variables consisting of broad social categories (working class, other employees and cooperative peasants) are available. In 1992, the distinction employee/self-employed was added. The 1996 Microcensus was the first to incorporate branch of activity and occupation in a more detailed classification.
} 
of the life-cycle profile of household income in favor of its labor market profile. In terms of income per household, the specific importance of the age of the household head is close to zero in 1996 and the weight of the number of children almost disappeared. According to per capita income, the specific weight of the number of children almost halved. In univariate analysis based on the same data sources, the number of children itself explained 46 per cent of the variance of income per capita in households in prime age in 1988. By 1996, this had fallen as low as 27 per cent.

From the other side, the importance of labor market characteristics of individuals (in our analyses only household heads) increased. The manual/non-manual distinction, not perceptible in the communist period, re-appeared in both income indicators. In the structure of income per capita, education tripled in importance. All of these changes indicate that there was considerable income mobility, more specifically, that the position of non-manual and educated workers has improved while the number of manual and less skilled people worsened. There were certainly other important changes according to branch and sector of ownership, but unfortunately the available data do not allow a comparison over time.

\section{Towards a more transparent redistribution}

In contrast to obscure redistribution under the communist regime, income distribution was made more transparent after 1989. Price subsidies were abolished in mid-1990. By 1993, the wage tax (almost flat at the time) was replaced by a new progressive income tax and a new formula of employee and employer pension and health contributions was introduced. By 1996, the system of social benefits had been simplified and targeting introduced. In 1991, the official 'living minimum' was established. Since 1993 its level has served as a bench-mark for income testing of various social benefits within the state support scheme (especially family allowances). ${ }^{10}$ Overall, the distribution of market income has been visibly separated from its state redistribution through taxes, contributions and benefits.

The general level of redistribution in a country is typically displayed as the proportion of taxes and contributions in GDP (the so-called tax quota). The new system started on a rather high level of redistribution, nevertheless both tax and contribution rates decreased slowly but regularly until 1998. Currently, the Czech tax quota is located somewhere between the liberal Anglo-Saxon and social Scandinavian countries, close to Germany, and Austria (which redistribute somewhat less), the Netherlands and France (which redistribute somewhat more). According to the OECD, the composite (taxes plus contributions) tax quota in 1996 was 40.3 in the Czech Republic, 35.9 in the United Kingdom, 38.2 in Germany, 44.1 in Austria, 43.9 in the Netherlands, 45.7 in France and 51.9 in Sweden (OECD, 1997).

Unlike the macroeconomic calculation, it is not possible to examine distributional flows in their entirety the variety on a microlevel due to a variety of subjects (households and firms) and channels (through incomes and consumption). Our observation is limited to direct taxes paid by households (the wage tax in 1988 and income tax together with contributions for

\footnotetext{
${ }^{10}$ The subsistence income scheme calculates greater amounts for individual persons and lesser lump-sum amounts for families according to their size. The mode of calculation stresses personal needs and disregards common household expenditures, thus continuing to follow the communist 'needs' principle. The elasticity coefficient of the subsistence income with the size of household is 0.85 , in comparison with an average elasticity of 0.7 in Western countries, as reported by Buhman et al.1988.
} 
health and social insurance in 1996) and the state benefits they receive. ${ }_{\text {Moreover, for the }}$ sake of comparability over time, it is necessary to limit the analysis to the non-agricultural employee population. This is because co-operative farmers were not taxed under the communist regime and there were virtually no self-employed in 1988.

\section{Table 6}

The calculation of taxes and benefits according to income deciles on the comparative subsample reveal important changes over time (Table 6). While the amount of income tax and social contributions increased, social benefits decreased in this section of the population, by a similar level of around 5 percentage points. If we take the population as a whole, the rise in the financial burden of households is less striking, but still apparent (see Table 10 below). The diminishing 'social wage' provided in kind by state enterprises and/or trade unions (crèches and nursery schools, recreation, canteens, etc.) makes the transformation of the system even less advantageous for families with children.

Together with the growing financial burden, both taxes and social benefits are distributed more steeply among households, in accordance with the reform design. During the communist regime, wage tax (the rates of which were established in the late 1950s) completely lost its progressiveness, until the overwhelming majority of workers had advanced to its highest level (17 per cent). The progressiveness of the new system is evident despite the fact that the majority of the active population is still hit by the first band of income tax (15 per cent) and only very few by the second ( 20 per cent). Regarding social benefits, their targeting was the main purpose behind the new system of state social support introduced in 1996.

Table 7

Table 7 presents a regression analysis of taxes, social benefits and their summary redistributive effect. The relationship of taxation to both the number of active earners and especially children per household weakened, and the effect of household income on the tax level increased from a almost zero in 1988 to becoming a factor of prime importance among employees and of considerable importance among all households. The determination of social benefits took a similar course, but to a lesser extent. The shift documents the systemic change - generally speaking, Czech society has been moving from redistribution based on family lifecycle redistribution based on family income. Unlike the communist system of income distribution, which was shaped according to the basic needs of individuals, the new system stresses the economic capacity of the household.

\section{Moving closer to the West}

The changing income structure represents part of the general trend that is reintroducing the Czech Republic to the fold of 'standard' market countries. This is to be displayed using the Luxembourg Income Study (LIS), we selected countries representing the 'liberal' (USA, UK), 'social-market' (Austria, Germany), 'welfare' (Belgium, the Netherlands) and 'socialist' (Sweden) veins. Although most of the LIS data sets are less recent than the latest for the Czech Republic, it is still possible to compare national data on the legitimate assumption that

\footnotetext{
${ }^{11}$ The wage tax under the communist regime, which remained in place until the end of 1992, also included social security payments and state support of families with children. It differed by gender, age, marital status and the number of dependent children. It is thus legitimate to compare the wage tax with income tax plus contributions for health and social insurance.
} 
income distribution and structure changes much less rapidly in stabilized Western systems than in transitional countries, as Michael Förster's (2000) study witnesses.

Table 8

As Table 8 shows, changes occurring after 1989 certainly brought the Czech Republic closer to the West. In income per household, disparities are still higher in the Czech Republic than in West European countries. In contrast, the disparity of per capita income reached the level of 'socially generous' Western countries (Belgium and Sweden). We have to remember that it was especially households located above the lower bound value of the tenth income decile (P90) that profited from the transition: whereas the relative per capita income level of households at this limit in the Czech Republic in 1996 is around the level of Sweden or Belgium, the relative position of households at the lower bound value of the top income vintile (P95) is closer to the higher Dutch or German levels.

The second cross-national comparison concerns the determination of household income. As correlations of income per household with income per capita in the last column of Table 8 illustrate, the distance between the two income distributions characteristic for the communist regime seems already to have disappeared. Their increasing interrelationship indirectly indicates a weakening of demographic factors and social transfers in income packaging and, correspondingly, a strengthening dependency of income on labor market participation and the human capital of adult members. Statistically speaking, this means that actual family welfare is less sensitive on income indicator and that the mode of adjustment of income to family needs has less importance than before.

Table 9

To gain a more detailed look at the generation of inequalities, we compare the importance of basic demographic determinants in the collection of household income. Table 9 shows that in cross-national comparison, the percentage of variance explained by these variables was so high in pre-1989 Czech Republic that only Sweden could compete with it. Now this percentage has decreased to a level much closer to Western countries and puts the Czech Republic somewhere between 'social-market' (such as Germany) and 'liberal' (such as the UK) countries. This concerns both the income per household (and the weight of the number of active earners in its formation) and income per capita (and corresponding weight of the number of dependent children).

Table 10

The third comparison concerning the level and degree of redistribution through taxes and social transfers presents the Czech Republic as a rather unique case (Table 10). It is much more redistributive in taxes and considerably more redistributive in social benefits that any other OECD country under observation. Here, we should be aware of the fact that the steep distribution of taxes is largely due to the continuing non-taxation of pension benefits and that pensioners continue to occupy the bottom of distribution in a considerable degree. Due to this, the Czech Republic belongs to the liberal model in both tax and transfer distribution. The reform of the system which started to be introduced in 1993 has even strengthened redistributional flows. ${ }^{12}$ The targeting of benefits did not affect the very bottom of the income distribution (mostly pensioners), but the second quintile (poor families with children).

\footnotetext{
${ }^{12}$ As Gardiner (1997) documents, the redistributive effect of tax and transfer policy has also recently increased in most Western countries.
} 
The available indicators do not allow us to compare the labor market and human capital characteristics of households across countries and thus to document more precisely the current situation in the Czech Republic. Nevertheless, even with the indicators at our disposal, it can be concluded that the distribution of household income in the Czech Republic is much less different from Western countries regarding inequality and its structure in 1996 than in 1988. Only the equalizing effect of taxes and social benefits continues to be rather extreme: a huge amount of transfers (as in social-democratic countries) is combined with a steep slope of redistribution (as in liberal countries).

\section{Conclusion and discussion}

Using three large statistical surveys of household income, we detected changes in the range and structure of income, and examined whether the Czech Republic has escaped from the model of income distribution centered on the basic reproduction of individuals and is approaching a market model. Between 1988 and 1996, the range of income inequality increased considerably. The income hierarchy remained fixed at the bottom, and opened up, reducing income share of middle categories. Whereas in 1988, pensioners almost exclusively occupied the bottom decile, to a considerable extent they moved to the lower middle income ladders to be partly replaced by families with children. Household income is much less determined by demographic variables today than in the former regime.

With regard to direct income redistribution, the state takes more from and gives less to households. Number of children is no longer the prominent factor of both taxes and transfers as it was in the communist regime. Instead, household income has become the dominant determinant of taxes, and also a more important determinant of social transfer. At the same time, flows of redistribution strengthened, be it in connection with tax reform (more progression) or social reform (more targeting). The equalizing intervention of the state in favor of the poor and near-poor (and to the detriment of the middle classes) appears to be very high in comparison with even the most redistributive Western countries.

In our analysis of nominal household income, we omitted several factors which contribute to family welfare and its distribution: the informal economy, relative prices, and the quality of consumer goods and services. In all these areas, important changes have also occurred. As it is very difficult to measure them, we will only briefly comment on them.

Firstly, the size of the informal economy certainly increased, alongside the reduced ability and will of the state to control keeping of market rules. Observing the gap between income and consumption (including the huge increase in expenditures on cars, houses and recreation), economists consider that the official national income figures in the first half of 1990s underestimate it by about 20 per cent (Benacek, 1994; Vecernik, 1996, chapter 8). Obviously, new sources of income are very unevenly distributed among the population. Whereas employee households living exclusively from wages and those dependent on social transfers are disadvantaged, the self-employed and businessmen are favored. The double status of being employed full-time and at the same time self-employed part-time is also widespread. The extremely high incomes of the privatization insiders are completely obscured by official income figures.

Secondly, relative prices have changed considerably. This was initially due to the abolition of price subsidies on 'basic goods' and the price burden of 'luxury goods', and later due to the 
play of market forces, including the operation of market chains and Vietnamese bazaars pushing prices down. As the prices of foodstuffs and the prices of other (industrial) goods rose differently, the gap between them disappeared and a variety of goods and prices began to provide a much larger consumer choice. At the same time, the costs of housing increased considerably, however not on the market level, due to continuing state regulation. Thus, the previously varied costs of housing for rented, co-operative and family-owned apartments converged. At the same time, however, black housing market appeared, due to rent regulation.

Thirdly, the quality of consumer goods and services improved considerably. Open borders and market competition enhanced both the supply and quality of most goods. In place of the formerly uniform and mostly inferior supply, customers may now choose from a huge range of domestic and imported goods of much higher quality, especially in the area of electronics, automobiles, textiles and furniture. They can also use previously unavailable possibilities for travel. The Consumer Price Index fails to reflect such a tremendous change in quality and choice. Moreover, health and life expectancy have improved due to better supply of pharma products and the radical change in diet, facilitated by a decrease in the consumption of meat (encouraged before by subsidized prices and a lack of alternatives) and an increase in the consumption of fruits and vegetables (limited before by scarce supply and variety).

It is not easy to assess or, even, accurately measure the effect of these various changes on family welfare. Without a doubt, the real level of household welfare is higher than income surveys suggest. If informal income were included, disparities in family welfare income would be likely to increase. Regardless, all households could benefit some way from easier accessibility to a wider selection of better quality goods and services.

Our story ends by 1996 income data which, fortunately, already reflect major tax and social reforms. In mid-1997, the recession hit, doubling the unemployment rate and slowing the rise of wages and pension benefits. But the qualitative change of the system of income distribution was not hindered by it, as small sociological surveys document. Only to confirm these trends on large sample we will have to wait until mid-2004 when the next Microcensus envisaged to be conducted in March 2003 will be available. 


\section{References}

Atkinson, A.B., Micklewright, J. (1992) The Economic Transformation of Eastern Europe and the Distribution of Income, Cambridge: Cambridge University Press.

Atkinson, A.B., Rainwater, L. and Smeeding, T.M. (1995) Income Distribution in OECD Countries. Evidence from the Luxembourg Income Study, Paris: OECD.

Benacek, V. (1994) Small business and private entrepreneurship during transformation: The case of the Czech republic, Working Papers No. 53, Prague: CERGE/EI.

Buhmann, B., Rainwater, L., Schmaus, G., and Smeeding, T.M. (1988) 'Equivalence scales, well-being, inequality, and poverty: sensitivity estimates across the countries using the Luxembourg Income Study (LIS) database', The Review of Income and Wealth 34: 115-142.

Flemming, J. and Micklewright, J. (1999) Income distribution, economic systems and transition, Innocenti Occasional Papers, Economic and Social Policy Series No. 70, Florence: UNICEF.

Förster, M.F. (2000) Trends and driving factors in income distribution and poverty in OECD area, Labor Market and Social Policy Occasional Papers No. 42, Paris: OECD.

Gardiner, K. (1997) 'A survey of income inequality over the last twenty years - how does the UK compare?', in: Gottchalk, P., Gustafsson, B. and Palmer, E. (eds.), Changing Patterns in the Distribution of Economic Welfare. An International Perspective, Cambridge: Cambridge University Press, pp. 36-59.

Incomes (1967) in Postwar Europe: A Study of Policies, Growth and Distribution, Geneva: United Nations.

Marx, K. ([1867] 1965) Capital, Vol. 1, Moscow: Progress Publishers.

(The) OECD (1997) Jobs Strategy. Making Work Pay: Taxation, Benefits, Employment and Unemployment, Paris: OECD.

Rainwater, L. (1994) 'Family equivalence as a social construction', in: Ekert-Jaffe, O. (ed.) Standards of Living and Families: Observation and Analysis, Paris: John Libby Eurotext.

Vecernik, J. (1986) Wage and income disparity: analysis of some issues (in Czech), Prague: The Institute for Philosophy and Sociology, Academy of Sciences.

Vecernik, J. (1996) Markets and People. The Czech Reform Experience in a Comparative Perspective, Avebury: Aldershot.

Vecernik, J. (1999) 'The middle classes in the Czech reforms: The interplay between policies and social stratification', Communist and Post-Communist Studies, 32: 397-416.

Wiles, P. (1974) Distribution of Income: East and West, Amsterdam: North Holland Publishing Company.

Wiles, P. (1978) 'Our shaky database', in: Krelle, W. and Shorrocks, A.P. (eds.) Personal Income Distribution, Amsterdam: North Holland Publishing Company. 
Schema 1 Income distribution under command and market economy

\begin{tabular}{|c|c|c|}
\hline Characteristic & Command economy & Market economy \\
\hline Generator of inequality & mainly the state & mainly the labor market \\
\hline Distribution according to & basic needs & skills, performance \\
\hline $\begin{array}{l}\text { Main factors of inequality } \\
\text { in earnings }\end{array}$ & $\begin{array}{l}\text { gender, age, hard manual } \\
\text { labor, loyalty to the regime }\end{array}$ & $\begin{array}{l}\text { human capital, managerial } \\
\text { position, risk-taking }\end{array}$ \\
\hline $\begin{array}{l}\text { Main factors of inequality } \\
\text { in household income }\end{array}$ & $\begin{array}{l}\text { number of active earners } \\
\text { and dependent children }\end{array}$ & $\begin{array}{l}\text { disparities in family adult } \\
\text { members' earnings }\end{array}$ \\
\hline $\begin{array}{l}\text { Family expenditures } \\
\text { mostly spent on }\end{array}$ & $\begin{array}{l}\text { food and other } \\
\text { individualized items in } \\
\text { contrast to low shared } \\
\text { costs (housing) }\end{array}$ & $\begin{array}{l}\text { housing, services, few of } \\
\text { individualized items in } \\
\text { contrast to high shared } \\
\text { costs }\end{array}$ \\
\hline Economies of scale & rather low & quite high \\
\hline $\begin{array}{l}\text { Appropriate income } \\
\text { indicator }\end{array}$ & $\begin{array}{l}\text { per capita income } \\
\text { (or adjusted to steep } \\
\text { equivalent units) }\end{array}$ & $\begin{array}{l}\text { per household income } \\
\text { (or adjusted to flat } \\
\text { equivalent units) }\end{array}$ \\
\hline $\begin{array}{l}\text { Correlation of income per } \\
\text { household with per capita }\end{array}$ & weak & strong \\
\hline $\begin{array}{l}\text { 'Ideological' unit of } \\
\text { observation }\end{array}$ & $\begin{array}{l}\text { individual conceived as } \\
\text { future, current or past } \\
\text { worker }\end{array}$ & $\begin{array}{l}\text { family, household as a } \\
\text { economic and social unit }\end{array}$ \\
\hline
\end{tabular}


Table 1 Characteristics of Czech income surveys

\begin{tabular}{lccc}
\hline Characteristic & 1988 & 1992 & 1996 \\
\hline Targeted per cent of households & 2 & 0.5 & 1 \\
Survey sample (N of households) & 69,912 & 15,677 & 27,314 \\
Non-response rate in percentage of households & 4.2 & 15.7 & 23.8 \\
\hline $\begin{array}{l}\text { Household income per capita according to income } \\
\text { surveys }\end{array}$ & & & \\
- in nominal terms (thousands CZK yearly) & 22.3 & 33.7 & 63.5 \\
- growth in real terms (1988=100) & 100.0 & 78.1 & 93.4 \\
\hline Population income per capita according to & & & \\
aggregate statistics & & & 83.5 \\
- in nominal terms (thousands CZK yearly) & 25.9 & 42.0 & 103.7 \\
- growth in real terms (1988=100) & 100.0 & 84.2 & 76.0 \\
\hline Coverage of income surveys in comparison to & 86.1 & 80.2 & \\
aggregate statistics & & & \\
\hline Sources: & & & \\
\hline
\end{tabular}

Sources: Microcensus 1988, 1992 and 1996, Statistical Yearbooks, Czech National Bank.

*) Income per capita in surveys is weighted by persons.

**) According to the Balance of Incomes and Expenditures of the Population in 1988 and 1992 and National Accounts in 1996. 
Table 2 Characteristics of distribution of household income

\begin{tabular}{|c|c|c|c|c|c|c|}
\hline \multirow[t]{2}{*}{ Indicator } & \multicolumn{3}{|c|}{ Per household } & \multicolumn{3}{|c|}{ Per capita } \\
\hline & 1988 & 1992 & 1996 & 1988 & 1992 & 1996 \\
\hline \multicolumn{7}{|c|}{ Coefficients and decile ratio: } \\
\hline Variation & 0.53 & 0.69 & 0.73 & 0.40 & 0.56 & 0.65 \\
\hline Gini coefficient & 0.29 & 0.32 & 0.33 & 0.20 & 0.23 & 0.26 \\
\hline Decile ratio (D90/D10) & 5.12 & 4.95 & 5.21 & 2.43 & 2.51 & 2.91 \\
\hline \multicolumn{7}{|c|}{ Correlations with household size and composition (Pearson coefficients): } \\
\hline Number of all members & 0.59 & 0.55 & 0.52 & -0.64 & -0.51 & -0.15 \\
\hline Number of active earners & 0.73 & 0.59 & 0.61 & 0.04 & 0.10 & 0.18 \\
\hline Number of children & 0.29 & 0.28 & 0.28 & -0.75 & -0.59 & -0.21 \\
\hline \multicolumn{7}{|c|}{ Correlations with other income indicators (Pearson coefficients): } \\
\hline Per capita & 0.45 & 0.65 & 0.67 & - & - & - \\
\hline OECD equivalent unit & 0.70 & 0.82 & 0.95 & 0.95 & 0.97 & 0.97 \\
\hline LIS equivalent unit & 0.77 & 0.87 & 0.88 & 0.88 & 0.94 & 0.94 \\
\hline Square root & 0.88 & 0.94 & 0.82 & 0.82 & 0.91 & 0.91 \\
\hline
\end{tabular}

Sources: Microcensus 1988, 1992 and 1996.

All coefficients are significant on the level $<0.001$. 
Table 3 Distribution of household income and the real growth by income deciles (per cent )

\begin{tabular}{lrrrrrrrr}
\hline $\begin{array}{l}\text { Income } \\
\text { decile }\end{array}$ & \multicolumn{3}{c}{ Per household (PH) } & \multicolumn{3}{c}{ Per capita (PC) } & \multicolumn{2}{c}{ Real growth in 1988-1996 } \\
\cline { 2 - 8 } & 1988 & 1992 & 1996 & 1988 & 1992 & 1996 & PH & PC \\
\hline 1 & 2.5 & 2.9 & 2.8 & 5.3 & 4.9 & 4.3 & 105.6 & 74.6 \\
2 & 4.1 & 4.1 & 3.9 & 6.6 & 6.4 & 5.9 & 88.5 & 82.8 \\
3 & 5.9 & 5.8 & 5.6 & 7.4 & 7.3 & 6.8 & 88.7 & 85.9 \\
4 & 7.6 & 6.9 & 6.7 & 8.1 & 7.9 & 7.6 & 81.7 & 87.7 \\
5 & 9.3 & 8.1 & 7.9 & 8.8 & 8.6 & 8.3 & 79.7 & 88.5 \\
6 & 10.7 & 9.6 & 9.4 & 9.6 & 9.2 & 9.1 & 81.4 & 88.6 \\
7 & 12.0 & 11.1 & 10.9 & 10.6 & 10.1 & 10.1 & 84.5 & 89.2 \\
8 & 13.2 & 12.8 & 12.7 & 11.8 & 11.3 & 11.5 & 88.9 & 90.8 \\
9 & 15.1 & 15.2 & 15.4 & 13.6 & 13.2 & 13.7 & 95.0 & 93.7 \\
10 & 19.6 & 23.5 & 24.7 & 18.2 & 21.1 & 22.6 & 117.3 & 116.1 \\
Total & 100.0 & 100.0 & 100.0 & 100.0 & 100.0 & 100.0 & 93.4 & 93.4 \\
\hline
\end{tabular}

Sources: Microcensus 1988, 1992 and 1996. 
Table 4 Distribution of children and pensioners by income deciles

\begin{tabular}{|c|c|c|c|c|c|c|c|c|}
\hline \multirow{3}{*}{$\begin{array}{l}\text { Income } \\
\text { decile }\end{array}$} & \multicolumn{4}{|c|}{ According to income per household } & \multicolumn{4}{|c|}{ According to income per capita } \\
\hline & \multicolumn{2}{|c|}{$\begin{array}{c}\text { Share } \\
\text { of children }\end{array}$} & \multicolumn{2}{|c|}{$\begin{array}{c}\text { Share } \\
\text { of pensioners }\end{array}$} & \multicolumn{2}{|c|}{$\begin{array}{c}\text { Share } \\
\text { of children }\end{array}$} & \multicolumn{2}{|c|}{$\begin{array}{c}\text { Share } \\
\text { of pensioners }\end{array}$} \\
\hline & 1988 & 1996 & 1988 & 1996 & 1988 & 1996 & 1988 & 1996 \\
\hline 1 & 0.1 & 1.0 & 16.0 & 13.5 & 14.1 & 19.3 & 11.1 & 2.5 \\
\hline 2 & 1.1 & 2.8 & 14.9 & 12.0 & 14.2 & 16.5 & 9.9 & 4.9 \\
\hline 3 & 2.7 & 4.2 & 16.9 & 19.6 & 13.8 & 13.0 & 9.6 & 9.9 \\
\hline 4 & 6.7 & 6.3 & 13.0 & 17.3 & 13.2 & 9.3 & 9.6 & 16.7 \\
\hline 5 & 10.4 & 11.7 & 9.5 & 9.1 & 12.6 & 8.1 & 8.6 & 18.3 \\
\hline 6 & 13.3 & 14.5 & 7.1 & 7.3 & 11.3 & 7.7 & 9.0 & 16.2 \\
\hline 7 & 16.2 & 15.3 & 5.3 & 6.2 & 9.4 & 7.6 & 8.6 & 12.1 \\
\hline 8 & 17.4 & 15.6 & 4.9 & 5.6 & 6.7 & 6.9 & 9.6 & 8.1 \\
\hline 9 & 17.0 & 14.9 & 5.3 & 5.3 & 3.6 & 6.0 & 10.8 & 6.4 \\
\hline 10 & 15.0 & 13.6 & 7.0 & 4.3 & 1.2 & 5.5 & 13.1 & 5.0 \\
\hline Total & 100.0 & 100.0 & 100.0 & 100.0 & 100.0 & 100.0 & 100.0 & 100.0 \\
\hline
\end{tabular}

Sources: Microcensus 1988, 1992 and 1996. 
Table 5 Analysis of variance of (In) household income (per cent of total variance)

\begin{tabular}{|c|c|c|c|c|c|c|c|}
\hline \multirow[t]{2}{*}{ Factor } & \multirow{2}{*}{$\begin{array}{l}\text { No of ca- } \\
\text { tegories }\end{array}$} & \multicolumn{3}{|c|}{ Per household } & \multicolumn{3}{|c|}{ Per capita } \\
\hline & & 1988 & 1996 & 1996 & 1988 & 1996 & 1996 \\
\hline Main effects & & 62.82 & 43.73 & 48.88 & 59.26 & 48.22 & 53.75 \\
\hline $\mathrm{N}$ of active earners & 3 & 24.21 & 27.86 & 27.34 & 3.84 & 3.92 & 3.85 \\
\hline $\mathrm{N}$ of children & 5 & 5.42 & 2.40 & 2.84 & 31.84 & 19.43 & 22.79 \\
\hline Age of the head & 7 & 1.89 & 0.23 & 0.16 & 3.03 & 0.22 & 0.29 \\
\hline Non-manual & 2 & 0.16 & 0.70 & 0.53 & 0.00 & 1.43 & 0.76 \\
\hline Education & 4 & 3.29 & 3.45 & 4.88 & 1.19 & 3.59 & 4.79 \\
\hline Locality & 3 & 0.08 & 0.18 & 0.18 & 0.07 & 0.64 & 0.64 \\
\hline Branch & & - & - & 1.58 & - & - & 1.35 \\
\hline 2-ways interactions & & 3.16 & 2.36 & $*$ & 2.60 & 1.75 & $*$ \\
\hline Explained & & 65.98 & 46.08 & 48.88 & 61.86 & 49.97 & 48.88 \\
\hline
\end{tabular}

Sources: Microcensus 1988 and 1996.

Only households with head in prime age $(25-54)$.

All coefficients are significant on the level $<0.001$.

* Due to empty cells or a singular matrix, higher order interactions are not available. 
Table 6 Relative taxes and social benefits by income deciles (per cent)

\begin{tabular}{|c|c|c|c|c|c|c|c|c|}
\hline \multirow{3}{*}{$\begin{array}{l}\text { Income } \\
\text { decile }\end{array}$} & \multicolumn{4}{|c|}{ According to income per household } & \multicolumn{4}{|c|}{ According to income per capita } \\
\hline & \multicolumn{2}{|c|}{ Taxes } & \multicolumn{2}{|c|}{ Social benefits } & \multicolumn{2}{|c|}{ Taxes } & \multicolumn{2}{|c|}{ Social benefits } \\
\hline & 1988 & 1996 & 1988 & 1996 & 1988 & 1996 & 1988 & 1996 \\
\hline 1 & 16.1 & 16.6 & 17.0 & 17.9 & 10.3 & 11.9 & 30.1 & 30.5 \\
\hline 2 & 14.1 & 16.0 & 23.4 & 22.0 & 11.9 & 14.8 & 24.0 & 22.0 \\
\hline 3 & 13.6 & 16.3 & 24.2 & 21.8 & 13.0 & 16.4 & 20.4 & 17.6 \\
\hline 4 & 14.4 & 17.2 & 21.2 & 18.3 & 13.7 & 17.4 & 18.0 & 15.5 \\
\hline 5 & 14.9 & 18.0 & 18.5 & 15.4 & 14.1 & 18.3 & 16.6 & 14.1 \\
\hline 6 & 15.2 & 18.2 & 16.6 & 13.6 & 14.8 & 18.8 & 15.3 & 13.8 \\
\hline 7 & 15.3 & 19.7 & 15.6 & 11.2 & 15.4 & 19.8 & 14.4 & 11.7 \\
\hline 8 & 15.7 & 20.2 & 14.7 & 9.9 & 16.0 & 20.4 & 14.2 & 10.1 \\
\hline 9 & 16.0 & 21.4 & 13.8 & 7.8 & 17.2 & 21.6 & 14.1 & 7.8 \\
\hline 10 & 16.1 & 24.1 & 12.4 & 4.8 & 17.4 & 24.6 & 15.4 & 4.4 \\
\hline Total & 15.3 & 20.0 & 16.7 & 11.9 & 15.3 & 20.0 & 16.7 & 11.9 \\
\hline
\end{tabular}

Sources: Microcensus 1988 and 1996.

Only households of non-agricultural employees.

Relative tax is computed as the percentage of income tax and social contributions in gross household income.

Relative social benefits are computed as the percentage of social benefits in net household income. 
Table 7 Regression analysis of relative taxes and social benefits (standardized beta coefficients)

\begin{tabular}{|c|c|c|c|c|c|c|c|}
\hline \multirow[t]{2}{*}{ Factor } & \multirow{2}{*}{$\begin{array}{l}\mathrm{N} \text { of } \\
\text { cate- } \\
\text { gories }\end{array}$} & \multicolumn{2}{|c|}{$\begin{array}{c}\text { Taxes and } \\
\text { contributions }\end{array}$} & \multicolumn{2}{|c|}{ Social benefits } & \multicolumn{2}{|c|}{ Summary effect } \\
\hline & & 1988 & 1996 & 1988 & 1996 & 1988 & 1996 \\
\hline \multicolumn{8}{|c|}{ Employee households*) } \\
\hline $\mathrm{N}$ of active earners & 3 & 0.19 & 0.06 & -0.31 & -0.32 & -0.28 & -0.25 \\
\hline $\mathrm{N}$ of children & 5 & -0.53 & -0.31 & 0.38 & 0.18 & 0.47 & 0.23 \\
\hline Age of the head & 7 & 0.04 & -0.01 & -0.02 & 0.03 & -0.03 & 0.02 \\
\hline Household income & metric & 0.01 & 0.43 & 0.04 & -0.10 & 0.02 & -0.22 \\
\hline $\mathrm{R}^{2}$ & & 0.33 & 0.29 & 0.24 & 0.18 & 0.30 & 0.21 \\
\hline \multicolumn{8}{|l|}{ All households } \\
\hline $\mathrm{N}$ of active earners & 3 & 0.63 & 0.52 & -0.62 & -0.61 & -0.64 & -0.60 \\
\hline $\mathrm{N}$ of children & 5 & -0.31 & -0.16 & 0.15 & 0.05 & 0.20 & 0.08 \\
\hline Age of the head & 10 & -0.37 & -0.32 & 0.46 & 0.39 & 0.45 & 0.38 \\
\hline Household income & metric & -0.01 & 0.23 & -0.01 & -0.07 & 0.00 & -0.11 \\
\hline $\mathrm{R}^{2}$ & & 0.57 & 0.67 & 0.78 & 0.79 & 0.77 & 0.79 \\
\hline
\end{tabular}

Sources: Microcensus 1988 and 1996.

*) Only households of non-agricultural employees with head in prime age (25-54).

Relative tax and social benefits are calculated the same way as in Table 6. Summary effect is computed as benefits - taxes in percentages of net household income.

All coefficients are significant on the level $<0.001$. 
Table 8 Distribution of household income in OECD countries

\begin{tabular}{|c|c|c|c|c|c|c|c|c|}
\hline \multirow[t]{2}{*}{ Country } & \multirow[t]{2}{*}{ Year } & \multicolumn{5}{|c|}{ Per cent of median income } & \multirow[t]{2}{*}{ P90/P10 } & \multirow{2}{*}{$\begin{array}{l}\text { Correlation } \\
\mathrm{PH} / \mathrm{PC}^{*}\end{array}$} \\
\hline & & P10 & $\mathrm{P} 25$ & P75 & P90 & P95 & & \\
\hline \multicolumn{9}{|c|}{ Per household: } \\
\hline Belgium & 1988 & 47.9 & 70.3 & 133.7 & 172.2 & 200.8 & 3.59 & 0.56 \\
\hline France & 1984 & 45.9 & 68.8 & 139.4 & 193.7 & 238.6 & 4.22 & 0.61 \\
\hline Germany & 1984 & 45.8 & 68.8 & 134.1 & 178.6 & 213.8 & 3.90 & 0.62 \\
\hline Netherlands & 1987 & 50.8 & 72.9 & 134.4 & 181.7 & 216.9 & 3.58 & 0.60 \\
\hline Sweden & 1987 & 39.0 & 61.8 & 136.7 & 164.5 & 183.7 & 4.22 & 0.48 \\
\hline UK & 1986 & 41.2 & 62.9 & 146.7 & 204.7 & 240.2 & 4.97 & 0.65 \\
\hline USA & 1986 & 31.8 & 58.0 & 149.2 & 210.1 & 252.1 & 6.61 & 0.64 \\
\hline Czech & 1988 & 31.8 & 58.6 & 132.6 & 162.7 & 182.9 & 5.12 & 0.45 \\
\hline Republic & 1996 & 38.7 & 65.6 & 147.4 & 201.6 & 246.2 & 5.21 & 0.67 \\
\hline \multicolumn{9}{|l|}{ Per capita: } \\
\hline Belgium & 1988 & 56.9 & 73.8 & 134.2 & 174.1 & 201.6 & 3.06 & 0.61 \\
\hline France & 1984 & 47.5 & 68.2 & 144.9 & 206.1 & 253.9 & 4.33 & 0.64 \\
\hline Germany & 1984 & 54.3 & 73.3 & 141.9 & 193.2 & 230.9 & 3.56 & 0.70 \\
\hline Netherlands & 1987 & 55.8 & 72.5 & 140.6 & 192.8 & 228.3 & 3.50 & 0.68 \\
\hline Sweden & 1987 & 58.2 & 77.1 & 136.6 & 171.7 & 194.2 & 2.95 & 0.45 \\
\hline UK & 1986 & 45.6 & 68.5 & 144.7 & 203.9 & 247.9 & 4.47 & 0.68 \\
\hline USA & 1986 & 33.2 & 60.7 & 157.3 & 232.0 & 288.4 & 6.99 & 0.70 \\
\hline Czech & 1988 & 66.8 & 81.1 & 128.7 & 162.5 & 185.5 & 2.43 & 0.37 \\
\hline Republic & 1996 & 60.9 & 78.6 & 131.2 & 177.1 & 220.3 & 2.91 & 0.68 \\
\hline
\end{tabular}

Sources: Atkinson, Rainwater and Smeeding, 1995 (Table 4.10), LIS database, Microcensus 1988 and 1996. *) Pearson correlation coefficients between per household (PH) and per capita (PC) income. In the lower part weighted by persons. 
Table 9 Analysis of variance of (ln) household income in OECD countries (per cent of total variance)

\begin{tabular}{lcccrrrr}
\hline Factor & $\begin{array}{c}\text { Germany } \\
1987\end{array}$ & $\begin{array}{c}\text { Netherlan } \\
\text { ds } 1987\end{array}$ & $\begin{array}{c}\text { Sweden } \\
1987\end{array}$ & $\begin{array}{c}\text { UK } \\
1986\end{array}$ & $\begin{array}{r}\text { USA } \\
1986\end{array}$ & \multicolumn{2}{c}{ Czech Republic } \\
1988 & 1996 \\
\hline Per household: & & & & & & & \\
Main effects & 36.04 & 16.57 & 52.04 & 24.33 & 25.98 & 59.33 & 33.37 \\
N of active earners & 22.95 & 11.31 & 25.59 & 22.33 & 18.16 & 37.11 & 28.56 \\
N of children & 2.52 & 0.67 & 1.48 & $0.30 *$ & 0.22 & 7.79 & 2.85 \\
Age of the head & 3.96 & 2.47 & 1.59 & 0.61 & 2.24 & 1.62 & 0.34 \\
2-way interactions & 4.88 & $* *$ & $* *$ & 2.65 & 1.23 & 2.58 & 1.94 \\
Explained & 40.93 & 16.57 & 52.04 & 26.97 & 27.20 & 61.91 & 35.31 \\
\hline Per capita: & & & & & & & \\
Main effects & 38.37 & 33.77 & 50.06 & 36.80 & 31.62 & 57.39 & 33.38 \\
N of active earners & 3.17 & 1.43 & 2.72 & 4.91 & 3.52 & 4.70 & 4.09 \\
N of children & 30.12 & 25.69 & 40.29 & 24.98 & 24.87 & 32.72 & 18.72 \\
Age of the head & 1.28 & 0.63 & 1.24 & 1.01 & 1.68 & 3.20 & 0.52 \\
2-way interactions & 4.19 & $* *$ & $* *$ & 4.38 & 1.86 & 1.54 & 1.91 \\
Explained & 42.56 & 33.77 & 50.06 & 41.18 & 33.48 & 58.93 & 35.29 \\
\hline
\end{tabular}

Sources: LIS database; Microcensus 1988 and 1996.

Only households of non- agricultural employees with head in prime age (25-54).

All coefficients (except those marked $*$ ) are significant on the level $<0.01$.

** Due to empty cells or a singular matrix, higher order interactions are not available. 
Table 10 Distribution of taxes and transfers in OECD countries by income quintiles (per cent)

\begin{tabular}{lcccrrrr}
\hline Income & Germany & Netherland & Sweden & UK & USA & \multicolumn{2}{c}{ Czech Republic } \\
quintile & 1987 & s 1987 & 1987 & 1986 & 1986 & 1988 & 1996 \\
\hline Taxes: & & & & & & & \\
1 & 5.5 & 10.3 & 6.3 & 4.5 & 3.8 & 1.7 & 1.8 \\
2 & 10.4 & 10.0 & 12.5 & 8.1 & 6.9 & 11.1 & 5.4 \\
3 & 17.0 & 16.2 & 17.7 & 15.9 & 13.9 & 20.2 & 14.1 \\
4 & 23.4 & 22.3 & 23.3 & 25.0 & 22.6 & 27.3 & 25.1 \\
5 & 43.7 & 41.2 & 40.1 & 46.4 & 52.7 & 39.7 & 53.6 \\
Total & 100.0 & 100.0 & 100.0 & 100.0 & 100.0 & 100.0 & 100.0 \\
Average & 24.4 & 36.4 & 32.5 & 21.4 & 21.2 & 14.8 & 20.2 \\
\hline Transfers: & & & & & & & \\
1 & 21.8 & 24.9 & 15.2 & 26.7 & 29.2 & 27.5 & 27.5 \\
2 & 22.2 & 21.3 & 25.8 & 25.9 & 21.2 & 23.4 & 30.6 \\
3 & 16.7 & 16.9 & 21.7 & 19.4 & 17.1 & 17.1 & 20.4 \\
4 & 21.0 & 17.7 & 19.9 & 16.1 & 17.5 & 15.8 & 12.7 \\
5 & 18.3 & 19.2 & 17.4 & 11.9 & 15.1 & 16.2 & 8.8 \\
Total & 100.0 & 100.0 & 100.0 & 100.0 & 100.0 & 100.0 & 100.0 \\
Average & 24.1 & 43.4 & 42.7 & 30.1 & 14.5 & 26.2 & 24.9 \\
\hline
\end{tabular}

Sources: LIS database; Microcensus 1988 and 1996.

Household income is adjusted to an equivalent unit which is computed as root square of the size of household. 


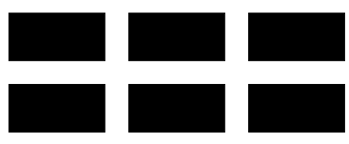

THE WILLIAM DAVIDSON INSTITUTE

AT THE UNIVERSITY OF MICHIGAN BUSINESSSCHOOL

\section{DAVIDSON INSTITUTE WORKING PAPER SERIES - Most Recent Papers}

The entire Working Paper Series is available at: www.wdi.bus.umich.edu

CURRENT AS OF 4/24/01

\begin{tabular}{|c|c|c|}
\hline Publication & Authors & Date \\
\hline $\begin{array}{l}\text { No. } 370 \text { From Needs to the Market: Changing Inequality of Household } \\
\text { Income in the Czech Transition }\end{array}$ & Jiri Vecernik & Apr. 2001 \\
\hline $\begin{array}{l}\text { No. } 369 \text { Competition and Corporate Governance: Substitutes or } \\
\text { Complements? Evidence from the Warsaw Stock Exchange }\end{array}$ & $\begin{array}{l}\text { Irena Grosfeld and Thierry } \\
\text { Tressel }\end{array}$ & Mar. 2001 \\
\hline $\begin{array}{l}\text { No. } 368 \text { Multinational Corporations as Catalyst for Industrial } \\
\text { Development: The Case of Poland }\end{array}$ & $\begin{array}{l}\text { Carlo Altomonte and Laura } \\
\text { Resmini }\end{array}$ & Feb. 2001 \\
\hline No. 367 A Multi-Task Theory of the State Enterprise Reform & $\begin{array}{l}\text { Chong-En Bai, David D. Li, } \\
\text { Zhigang Tao, and Yijiang Wang }\end{array}$ & Mar. 2001 \\
\hline No. 366 Confidence Building in Emerging Stock Markets & $\begin{array}{l}\text { Enrico C. Perotti, Luc Laeven, } \\
\text { and Pieter van Oijen }\end{array}$ & Dec. 2000 \\
\hline $\begin{array}{l}\text { No. } 365 \text { Incentive Contracting versus Ownership Reforms: Evidence } \\
\text { from China's Township and Village Enterprises }\end{array}$ & $\begin{array}{l}\text { Chun Chang, Brian McCall, and } \\
\text { Yijang Wang }\end{array}$ & Nov. 2000 \\
\hline $\begin{array}{l}\text { No. } 364 \text { Individual Pay and Outside Options: Evidence from the Polish } \\
\text { Labour Force Survey }\end{array}$ & $\begin{array}{l}\text { Fiona Duffy and Patrick Paul } \\
\text { Walsh }\end{array}$ & Mar. 2001 \\
\hline $\begin{array}{l}\text { No. } 363 \text { Investment, Credit Rationing and the Soft Budget Constraint: } \\
\text { Evidence from Czech Panel Data (revised Davidson Institute Working } \\
\text { Paper No. 60a) }\end{array}$ & Lubomír Lízal and Jan Svejnar & Feb. 2001 \\
\hline $\begin{array}{l}\text { No. } 362 \text { A Network Perspective on Inter-Organizational Transfer of } \\
\text { R\&D Capabilities: A Study of International Joint Ventures in Chinese } \\
\text { Automobile Industry }\end{array}$ & $\begin{array}{l}\text { Zheng Zhao, Jaideep Anand and } \\
\text { Will Mitchell }\end{array}$ & Feb. 2001 \\
\hline $\begin{array}{l}\text { No. } 361 \text { Network Restructuring and Firm Creation in East-Central } \\
\text { Europe: A Public-Private Venture }\end{array}$ & Gerald A. McDermott & Dec. 2000 \\
\hline $\begin{array}{l}\text { No. } 360 \text { Responses of Private and Public Schools to Voucher Funding: } \\
\text { The Czech and Hungarian Experience }\end{array}$ & $\begin{array}{l}\text { Randall K. Filer and Daniel } \\
\text { Münich }\end{array}$ & Oct. 2000 \\
\hline $\begin{array}{l}\text { No. } 359 \text { Labor Market Uncertainty and Private Sector Labor Supply in } \\
\text { Russia }\end{array}$ & Steven Stillman & Sept. 2000 \\
\hline $\begin{array}{l}\text { No. } 358 \text { Russian Roulette-Expenditure Inequality and Instability in } \\
\text { Russia, 1994-1998 }\end{array}$ & Branko Jovanovic & Sept. 2000 \\
\hline No. 357 Dealing with the Bad Loans of the Chinese Banks & John P. Bonin and Yiping Huang & Jan. 2001 \\
\hline No. 356 Retail Banking in Hungary: A Foreign Affair? & John P. Bonin and István Ábel & Dec. 2000 \\
\hline $\begin{array}{l}\text { No. } 355 \text { Optimal Speed of Transition: Micro Evidence from the Czech } \\
\text { Republic }\end{array}$ & $\begin{array}{l}\text { Stepan Jurajda and Katherine } \\
\text { Terrell } \\
\end{array}$ & Dec. 2000 \\
\hline No. 354 Political Instability and Growth in Dictatorships & $\begin{array}{l}\text { Jody Overland, Kenneth L. } \\
\text { Simons and Michael Spagat }\end{array}$ & Nov. 2000 \\
\hline No. 353 Disintegration and Trade & Jarko Fidrmuc and Jan Fidrmuc & Nov. 2000 \\
\hline $\begin{array}{l}\text { No. } 352 \text { Social Capital and Entrepreneurial Performance in Russia: A } \\
\text { Panel Study }\end{array}$ & Bat Batjargal & Dec. 2000 \\
\hline $\begin{array}{l}\text { No. 351 Entrepreneurial Versatility, Resources and Firm Performance in } \\
\text { Russia: A Panel Study }\end{array}$ & Bat Batjargal & Dec. 2000 \\
\hline $\begin{array}{l}\text { No. } 350 \text { The Dynamics of Entrepreneurial Networks in a Transitional } \\
\text { Economy: The Case of Russia }\end{array}$ & Bat Batjargal & Dec. 2000 \\
\hline
\end{tabular}




\begin{tabular}{|c|c|c|}
\hline $\begin{array}{l}\text { No. } 349 \text { R\&D and Technology Spillovers via FDI: Innovation and } \\
\text { Absorptive Capacity }\end{array}$ & Yuko Kinoshita & Nov. 2000 \\
\hline $\begin{array}{l}\text { No. } 348 \text { Microeconomic aspects of Economic Growth in Eastern } \\
\text { Europe and the Former Soviet Union, 1950-2000 }\end{array}$ & Sergei Guriev and Barry W. Ickes & Nov. 2000 \\
\hline $\begin{array}{l}\text { No. } 347 \text { Effective versus Statutory Taxation: Measuring Effective Tax } \\
\text { Administration in Transition Economies }\end{array}$ & $\begin{array}{l}\text { Mark E. Schaffer and Gerard } \\
\text { Turley }\end{array}$ & Nov. 2000 \\
\hline $\begin{array}{l}\text { No. } 346 \text { Objectives and Constraints of Entrepreneurs: Evidence from } \\
\text { Small and Medium Size Enterprises in Russia and Bulgaria }\end{array}$ & $\begin{array}{l}\text { Francesca Pissarides, Miroslav } \\
\text { Singer and Jan Svejnar }\end{array}$ & Oct. 2000 \\
\hline No. 345 Corruption and Anticorruption in the Czech Republic & $\begin{array}{l}\text { Lubomír Lízal and Evžen } \\
\text { Kočenda }\end{array}$ & Oct. 2000 \\
\hline No. 344 The Effects of Direct Foreign Investment on Domestic Firms & Jozef Konings & Oct. 2000 \\
\hline No. 343 On the Identification of Relative Wage Rigidity Dynamics & Patrick A. Puhani & Oct. 2000 \\
\hline $\begin{array}{l}\text { No. } 342 \text { The Determinants of Foreign Direct Investment in Transition } \\
\text { Economies }\end{array}$ & Alan A. Bevan and Saul Estrin & Oct. 2000 \\
\hline No. 341 The Global Spread of Stock Exchanges, 1980-1998 & Klaus Weber and Gerald F. Davis & Nov. 2000 \\
\hline $\begin{array}{l}\text { No. } 340 \text { The Costs and Benefits of Euro-isation in Central-Eastern } \\
\text { Europe Before or Instead of EMU Membership }\end{array}$ & D. Mario Nuti & Oct. 2000 \\
\hline No. 339 Debt Overhang and Barter in Russia & $\begin{array}{l}\text { Sergei Guriev, Igor Makarov and } \\
\text { Mathilde Maurel }\end{array}$ & Sept. 2000 \\
\hline $\begin{array}{l}\text { No. } 338 \text { Firm Performance and the Political Economy of Corporate } \\
\text { Governance: Survey Evidence for Bulgaria, Hungary, Slovakia and } \\
\text { Slovenia }\end{array}$ & $\begin{array}{l}\text { Patrick Paul Walsh and Ciara } \\
\text { Whela }\end{array}$ & July 2000 \\
\hline No. 337 Investment and Instability & $\begin{array}{l}\text { Nauro F. Campos and Jeffrey B. } \\
\text { Nugent }\end{array}$ & May 2000 \\
\hline $\begin{array}{l}\text { No. } 336 \text { The Evolution of the Insurance Sector in Central and } \\
\text { Eastern Europe and the former Soviet Union }\end{array}$ & Robert B.K. Pye & Aug. 2000 \\
\hline $\begin{array}{l}\text { No. } 335 \text { Institutional Technology and the Chains of Trust: Capital } \\
\text { Markets and Privatization in Russia and the Czech Republic }\end{array}$ & Bruce K & Aug. 2000 \\
\hline No. 334 The Evolution of Market Integration in Russia & $\begin{array}{l}\text { Daniel Berkowitz and David N. } \\
\text { DeJong }\end{array}$ & Aug. 2000 \\
\hline No. 333 Efficiency and Market Share in Hungarian Corporate Sector & László Halpern and Gábor Körösi & July 2000 \\
\hline No. 332 Search-Money-and-Barter Models of Financial Stabilization & $\begin{array}{l}\text { S.I. Boyarchenko and S.Z. } \\
\text { Levendorskii }\end{array}$ & July 2000 \\
\hline $\begin{array}{l}\text { No. } 331 \text { Worker Training in a Restructuring Economy: Evidence from } \\
\text { the Russian Transition }\end{array}$ & $\begin{array}{l}\text { Mark C. Berger, John S. Earle } \\
\text { and Klara Z. Sabirianova }\end{array}$ & Aug. 2000 \\
\hline $\begin{array}{l}\text { No. } 330 \text { Economic Development in Palanpur 1957-1993: A Sort of } \\
\text { Growth }\end{array}$ & Peter Lanjouw & Aug. 2000 \\
\hline $\begin{array}{l}\text { No. } 329 \text { Trust, Organizational Controls, Knowledge Acquisition from } \\
\text { the Foreign Parents, and Performance in Vietnamese International Joint } \\
\text { Ventures }\end{array}$ & $\begin{array}{l}\text { Marjorie A. Lyles, Le Dang } \\
\text { Doanh, and Jeffrey Q. Barden }\end{array}$ & June 2000 \\
\hline $\begin{array}{l}\text { No. } 328 \text { Comparative Advertising in the Global Marketplace: The } \\
\text { Effects of Cultural Orientation on Communication }\end{array}$ & $\begin{array}{l}\text { Zeynep Gürhan-Canli and } \\
\text { Durairaj Maheswaran }\end{array}$ & Aug. 2000 \\
\hline No. 327 Post Privatization Enterprise Restructuring & Morris Bornstein & July 2000 \\
\hline No. 326 Who is Afraid of Political Instability? & $\begin{array}{l}\text { Nauro F. Campos and Jeffrey B. } \\
\text { Nugent }\end{array}$ & July 2000 \\
\hline No. 325 Business Groups, the Financial Market and Modernization & Raja Kali & June 2000 \\
\hline $\begin{array}{l}\text { No. } 324 \text { Restructuring with What Success? A Case Study of Russian } \\
\text { Firms }\end{array}$ & Susan Linz & July 2000 \\
\hline $\begin{array}{l}\text { No. } 323 \text { Priorities and Sequencing in Privatization: Theory and } \\
\text { Evidence from the Czech Republic }\end{array}$ & $\begin{array}{l}\text { Nandini Gupta, John C. Ham and } \\
\text { Jan Svejnar }\end{array}$ & May 2000 \\
\hline $\begin{array}{l}\text { No. } 322 \text { Liquidity, Volatility, and Equity Trading Costs Across } \\
\text { Countries and Over Time }\end{array}$ & $\begin{array}{l}\text { Ian Domowitz, Jack Glen and } \\
\text { Ananth Madhavan }\end{array}$ & Mar. 2000 \\
\hline $\begin{array}{l}\text { No. } 321 \text { Equilibrium Wage Arrears: A Theoretical and Empirical } \\
\text { Analysis of Institutional Lock-In }\end{array}$ & $\begin{array}{l}\text { John S. Earle and Klara Z. } \\
\text { Sabirianova }\end{array}$ & Oct. 2000 \\
\hline No. 320 Rethinking Marketing Programs for Emerging Markets & $\begin{array}{l}\text { Niraj Dawar and Amitava } \\
\text { Chattopadhyay }\end{array}$ & June 2000 \\
\hline
\end{tabular}


No. 319 Public Finance and Low Equilibria in Transition Economies: the Role of Institutions

No. 318 Some Econometric Evidence on the Effectiveness of Active Labour Market Programmes in East Germany

No. 317 A Model of Russia's "Virtual Economy"

No. 316 Financial Institutions, Financial Contagion, and Financial Crises

No. 315 Privatization versus Regulation in Developing Economies: The Case of West African Banks

No. 314 Is Life More Risky in the Open? Household Risk-Coping and the Opening of China's Labor Markets

No. 313 Networks, Migration and Investment: Insiders and Outsiders in Tirupur's Production Cluster

No. 312 Computational Analysis of the Impact on India of the Uruguay Round and the Forthcoming WTO Trade Negotiations

No. 311 Subsidized Jobs for Unemployed Workers in Slovakia No. 310 Determinants of Managerial Pay in the Czech Republic

No. 309 The Great Human Capital Reallocation: An Empirical Analysis of Occupational Mobility in Transitional Russia

No. 308 Economic Development, Legality, and the Transplant Effect

No. 307 Community Participation, Teacher Effort, and Educational Outcome: The Case of El Salvador's EDUCO Program

No. 306 Gender Wage Gap and Segregation in Late Transition No. 305 The Gender Pay Gap in the Transition from Communism: Some Empirical Evidence

No. 304 Post-Unification Wage Growth in East Germany

No. 303 How Does Privatization Affect Workers? The Case of the

Russian Mass Privatization Program

No. 302 Liability for Past Environmental Contamination and Privatization

No. 301 Varieties, Jobs and EU Enlargement

No. 300 Employer Size Effects in Russia

No. 299 Information Complements, Substitutes, and Strategic Product Design

No. 298 Markets, Human Capital, and Inequality: Evidence from Rural China

No. 297 Corporate Governance in the Asian Financial Crisis

No. 296 Competition and Firm Performance: Lessons from Russia No. 295 Wage Determination in Russia: An Econometric Investigation

No. 294 Can Banks Promote Enterprise Restructuring?: Evidence From a Polish Bank's Experience

No. 293 Why do Governments Sell Privatised Companies Abroad?

No. 292 Going Public in Poland: Case-by-Case Privatizations, Mass Privatization and Private Sector Initial Public Offerings

No. 291a Institutional Technology and the Chains of Trust: Capital Markets and Privatization in Russia and the Czech Republic

No. 291 Institutional Technology and the Chains of Trust: Capital

Markets and Privatization in Russia and the Czech Republic

\begin{tabular}{|c|c|}
\hline $\begin{array}{l}\text { Daniel Daianu and Radu } \\
\text { Vranceanu }\end{array}$ & June 2000 \\
\hline $\begin{array}{l}\text { Martin Eichler and Michael } \\
\text { Lechner }\end{array}$ & June 2000 \\
\hline R.E Ericson and B.W Ickes & May 2000 \\
\hline $\begin{array}{l}\text { Haizhou Huang and Chenggang } \\
\mathrm{Xu}\end{array}$ & Mar. 2000 \\
\hline $\begin{array}{l}\text { Jean Paul Azam, Bruno Biais, and } \\
\text { Magueye Dia }\end{array}$ & Feb. 2000 \\
\hline John Giles & Apr. 2000 \\
\hline $\begin{array}{l}\text { Abhijit Banerjee and Kaivan } \\
\text { Munshi }\end{array}$ & Mar. 2000 \\
\hline $\begin{array}{l}\text { Rajesh Chadha, Drusilla K. } \\
\text { Brown, Alan V. Deardorff and } \\
\text { Robert M. Stern }\end{array}$ & Mar. 2000 \\
\hline Jan. C. van Ours & May 2000 \\
\hline $\begin{array}{l}\text { Tor Eriksson, Jaromir Gottvald } \\
\text { and Pavel Mrazek }\end{array}$ & May 2000 \\
\hline Klara Z. Sabirianova & Oct. 2000 \\
\hline $\begin{array}{l}\text { Daniel Berkowitz, Katharina } \\
\text { Pistor, and Jean-Francois Richard }\end{array}$ & Feb. 2000 \\
\hline Yasuyuki Sawada & Nov. 1999 \\
\hline Stepan Jurajda & May 2000 \\
\hline Andrew Newell and Barry Reilly & May 2000 \\
\hline Jennifer Hunt & Nov. 1998 \\
\hline Elizabeth Brainerd & May 2000 \\
\hline Dietrich Earnhart & Mar. 2000 \\
\hline $\begin{array}{l}\text { Tito Boeri and Joaquim Oliveira } \\
\text { Martins }\end{array}$ & May 2000 \\
\hline Todd Idson & Apr. 2000 \\
\hline $\begin{array}{l}\text { Geoffrey G. Parker and Marshall } \\
\text { W. Van Alstyne }\end{array}$ & Mar. 2000 \\
\hline $\begin{array}{l}\text { Dwayne Benjamin, Loren Brandt, } \\
\text { Paul Glewwe, and Li Guo }\end{array}$ & May 2000 \\
\hline $\begin{array}{l}\text { Simon Johnson, Peter Boone, } \\
\text { Alasdair Breach, and Eric } \\
\text { Friedman }\end{array}$ & Nov. 1999 \\
\hline J. David Brown and John S. Earle & Mar. 2000 \\
\hline $\begin{array}{l}\text { Peter J. Luke and Mark E. } \\
\text { Schaffer }\end{array}$ & Mar. 2000 \\
\hline John P. Bonin and Bozena Leven & Mar. 2000 \\
\hline $\begin{array}{l}\text { Bernardo Bortolotti, Marcella } \\
\text { Fantini and Carlo Scarpa }\end{array}$ & Mar. 2000 \\
\hline Wolfgang Aussenegg & Dec. 1999 \\
\hline Bruce Kogut and Andrew Spicer & Feb. 2001 \\
\hline Bruce Kogut and Andrew Spicer & Mar. 1999 \\
\hline
\end{tabular}




\begin{tabular}{|c|c|c|}
\hline No. 290 Banking Crises and Bank Rescues: The Effect of Reputation & Jenny Corbett and Janet Mitchell & Jan. 2000 \\
\hline $\begin{array}{l}\text { No. } 289 \text { Do Active Labor Market Policies Help Unemployed Workers to } \\
\text { Find and Keep Regular Jobs? }\end{array}$ & Jan C. van Ours & Feb. 2000 \\
\hline No. 288 Consumption Patterns of the New Elite in Zimbabwe & Russell Belk & Feb. 2000 \\
\hline $\begin{array}{l}\text { No. } 287 \text { Barter in Transition Economies: Competing Explanations } \\
\text { Confront Ukranian Data }\end{array}$ & $\begin{array}{l}\text { Dalia Marin, Daniel Kaufmann } \\
\text { and Bogdan Gorochowskij }\end{array}$ & Jan. 2000 \\
\hline $\begin{array}{l}\text { No. } 286 \text { The Quest for Pension Reform: Poland's Security through } \\
\text { Diversity }\end{array}$ & $\begin{array}{l}\text { Marek Góra and Michael } \\
\text { Rutkowski }\end{array}$ & Jan. 2000 \\
\hline No. 285 Disorganization and Financial Collapse & $\begin{array}{l}\text { Dalia Marin and Monika } \\
\text { Schnitzer }\end{array}$ & Oct. 1999 \\
\hline No. 284 Coordinating Changes in M-form and U-form Organizations & $\begin{array}{l}\text { Yingyi Qian, Gérard Roland and } \\
\text { Chenggang Xu }\end{array}$ & May 1999 \\
\hline $\begin{array}{l}\text { No. } 283 \text { Why Russian Workers Do Not Move: Attachment of Workers } \\
\text { Through In-Kind Payments }\end{array}$ & Guido Friebel and Sergei Guriev & Oct. 1999 \\
\hline No. 282 Lessons From Fiascos in Russian Corporate Governance & $\begin{array}{l}\text { Merritt B. Fox and Michael A. } \\
\text { Heller }\end{array}$ & Oct. 1999 \\
\hline $\begin{array}{l}\text { No. } 281 \text { Income Distribution and Price Controls: Targeting a Social } \\
\text { Safety Net During Economic Transition }\end{array}$ & $\begin{array}{l}\text { Michael Alexeev and James } \\
\text { Leitzel }\end{array}$ & Mar. 1999 \\
\hline $\begin{array}{l}\text { No. 280: Starting Positions, Reform Speed, and Economic Outcomes in } \\
\text { Transitioning Economies }\end{array}$ & William Hallagan and Zhang Jun & Jan. 2000 \\
\hline No. 279: The Value of Prominent Directors & $\begin{array}{l}\text { Yoshiro Miwa \& J. Mark } \\
\text { Ramseyer }\end{array}$ & Oct. 1999 \\
\hline No. 278: The Sy & János Kornai & Apr. 1998 \\
\hline $\begin{array}{l}\text { No. 277: The Developmental Consequences of Foreign Direct } \\
\text { Investment in the Transition from Socialism to Capitalism: The } \\
\text { Performance of Foreign Owned Firms in Hungary }\end{array}$ & Lawrence Peter King & Sept. 1999 \\
\hline $\begin{array}{l}\text { No. 276: Stability and Disorder: An Evolutionary Analysis of Russia's } \\
\text { Virtual Economy }\end{array}$ & $\begin{array}{l}\text { Clifford Gaddy and Barry W. } \\
\text { Ickes }\end{array}$ & Nov. 1999 \\
\hline $\begin{array}{l}\text { No. 275: Limiting Government Predation Through Anonymous } \\
\text { Banking: A Theory with Evidence from China. }\end{array}$ & $\begin{array}{l}\text { Chong-En Bai, David D. Li, } \\
\text { Yingyi Qian and Yijiang Wang }\end{array}$ & July 1999 \\
\hline No. 274: Transition with Labour Supply & Tito Boeri & Dec. 1999 \\
\hline $\begin{array}{l}\text { No. 273: Sectoral Restructuring and Labor Mobility: A Comparative } \\
\text { Look at the Czech Republic }\end{array}$ & Vit Sorm and Katherine Terrell & Nov. 1999 \\
\hline $\begin{array}{l}\text { No. 272: Published in: Journal of Comparative Economics "Returns to } \\
\text { Human Capital Under the Communist Wage Grid and During the } \\
\text { Transition to a Market Economy" Vol. 27, pp. 33-60 } 1999 .\end{array}$ & $\begin{array}{l}\text { Daniel Munich, Jan Svejnar and } \\
\text { Katherine Terrell }\end{array}$ & Oct. 1999 \\
\hline $\begin{array}{l}\text { No. 271: Barter in Russia: Liquidity Shortage Versus Lack of } \\
\text { Restructuring }\end{array}$ & $\begin{array}{l}\text { Sophie Brana and Mathilde } \\
\text { Maurel }\end{array}$ & June 1999 \\
\hline $\begin{array}{l}\text { No. 270: Tests for Efficient Financial Intermediation with Application to } \\
\text { China }\end{array}$ & Albert Park and Kaja Sehrt & Mar. 1999 \\
\hline $\begin{array}{l}\text { No. 269a: Russian Privatization and Corporate Governance: What Went } \\
\text { Wrong? }\end{array}$ & $\begin{array}{l}\text { Bernard Black, Reinier Kraakman } \\
\text { and Anna Tarassova }\end{array}$ & May 2000 \\
\hline $\begin{array}{l}\text { No. 269: Russian Privatization and Corporate Governance: What Went } \\
\text { Wrong? }\end{array}$ & $\begin{array}{l}\text { Bernard Black, Reinier Kraakman } \\
\text { and Anna Tarassova }\end{array}$ & Sept. 1999 \\
\hline No. 268: Are Russians Really Ready for Capitalism? & Susan Linz & Sept. 1999 \\
\hline No. 267: Do Stock Markets Promote Economic Growth? & $\begin{array}{l}\text { Randall K. Filer, Jan Hanousek } \\
\text { and Nauro Campos }\end{array}$ & Sept. 1999 \\
\hline $\begin{array}{l}\text { No. 266: Objectivity, Proximity and Adaptability in Corporate } \\
\text { Governance }\end{array}$ & $\begin{array}{l}\text { Arnoud W.A Boot and Jonathan } \\
\text { R. Macey }\end{array}$ & Sept. 1999 \\
\hline $\begin{array}{l}\text { No. 265: When the Future is not What it Used to Be: Lessons from the } \\
\text { Western European Experience to Forecasting Education and Training in } \\
\text { Transitional Economies }\end{array}$ & $\begin{array}{l}\text { Nauro F. Campos, Gerard } \\
\text { Hughes, Stepan Jurajda, and } \\
\text { Daniel Munich }\end{array}$ & Sept. 1999 \\
\hline $\begin{array}{l}\text { No. 264: The Institutional Foundation of Foreign-Invested Enterprises } \\
\text { (FIEs) in China }\end{array}$ & Yasheng Huang & Sept. 1999 \\
\hline $\begin{array}{l}\text { No. 263: The Changing Corporate Governance Paradigm: Implications } \\
\text { for Transition and Developing Countries }\end{array}$ & $\begin{array}{l}\text { Erik Berglof and Ernst-Ludwig } \\
\text { von Thadden }\end{array}$ & June 1999 \\
\hline
\end{tabular}

